\title{
A Study on the Reform of College English Teaching in China's Private Colleges and Universities.
}

\author{
Tong Yinping \\ International Education College, Xi’an Peihua University; Xi'an, China
}

Keywords: Private Colleges and Universities, College English Teaching, Reform, Students

\begin{abstract}
As an important part of higher education in China, private colleges and universities undertake heavy responsibilities. College English is a compulsory course for non-English undergraduates, involving the largest number of students and most majors in each college or university. However, it is undeniable that the teaching effect of college English is not satisfactory. This paper analyzes problems existing in current college English teaching in private colleges and universities, and then discusses some feasible reforms in different aspects, including curriculum setting, teaching mode and evaluation system.
\end{abstract}

\section{Introduction}

Since the late 1990s, China's higher education entered the most prosperous stage in Chinese history. Receiving higher education is no longer a privilege for elites, but for more and more people. Private colleges and universities conforms to the needs of social development, providing some more students with the opportunities to receive higher education, thus becoming an indispensable part of higher education in China. It is a great mission for teachers and educators to offer a high-quality education to students. College English is a compulsory course in the four years' study, which plays a significant role in the cultivation of talents. However, this course is also one of the most criticized courses due to the unsatisfactory teaching effect. Therefore, it is of great urgency to make a reform on college English teaching in private colleges and universities.

\section{Problems Existing in Current College English Teaching in Private Colleges and Universities}

Over the past 20 years, private colleges and universities have a booming development and got great achievements. However, the rapid development has also brought about various problems in different aspects. Owing to a short history of private colleges and universities, there are some problems in the following aspects:

\subsection{The Vague Teaching Objectives and not very Reasonable Curriculum Setting}

In the "College English curriculum requirements" (2007)made by the ministry of education, it is explicitly pointed out that the teaching objectives of college English are to cultivate students' comprehensive ability, especially listening and speaking skills, enhance students' ability of autonomous learning, improve students' comprehensive cultural attainments, and meet the growing needs of social development and international communication. The teaching objectives of college English in the "College English curriculum requirements" are further divided into three levels: general requirements, higher requirements and highest requirements. However, many universities have not set specific goals for their own students according to the actual English level of students. Therefore, college English has barely got good effects and received the most complaints from students although a large number of college students are learning English at present. Like in public universities, college English is offered in the freshman and sophomore years in private colleges and universities. Students of nearly every major must learn English as a compulsory course. In the junior and senior years, students have no English classes and there is a blank stage of English learning before graduation. The consequence is that many students can't communicate with others effectively in English after graduation. Usually, students think that the aim of English learning is to 
pass College English Test Band 4 and Band 6 and meet the basic requirements of the enterprises when they are hunting for jobs and that English learning is finished if they have passed CET 4 and CET 6. However, many students can't read English instructions of goods, business contracts , relevant materials, etc. while working, and even can't communicate with others in English. Moreover, college English textbooks are mostly published by Beijing Foreign Language Teaching and Research Press and Shanghai Foreign Language Education Press at present. Most of the textbooks are written to meet the needs of students in public universities. Some private universities use textbooks obviously not suitable for their own students, which is one of the elements of the unsatisfactory teaching effects. College English teaching in private colleges and universities should be different from that in public universities. They should have their own unique orientations and attach greater importance to students' practical abilities of using English, rather than blindly pursue high rate of passing CET 4. College English teaching in private colleges and universities should be related to students' potential careers in the future and serve students' future employment.

\subsection{The Aspect of Teaching Staff}

The majority of private colleges and universities were established after 1990s, thus they do not possess a powerful teachers' team. Most of those college English teachers are newly graduated graduate students. What's more, many teachers do not graduate from normal universities and have not completed relevant courses in pedagogy. Therefore, most teachers still adopt the traditional teaching mode, relying on the content in textbooks, focusing on vocabularies, long and difficult sentences and the exercises, just as the way they were taught when they were students. With a boring atmosphere in class, many students play mobile phones, read magazines and novels or sleep in class, and are less motivated to participate in class activities and even hate English classes. Many teachers ignore students' behaviors in class and deliver their teaching without students' cooperation in order to finish their teaching tasks. Not unexpectedly, the rare teacher-student interactions result in lower teaching efficiency. Those academic leaders of college English course in private colleges and universities are mainly some retired English professors from public universities. They have profound professional knowledge and rich teaching experience, but have no experience of teaching students in private universities before. While working in private colleges and universities, they just apply their previous experience to the management of college English teaching with no regard to students' actual English level. The number of students enrolled in one private university a year reaches up to 5,000, so teachers deliver English lectures to large class with heavy teaching tasks in many private universities. Many teachers are just busy completing their workload and teaching task without good teaching effects. There is also a problem that the number of students registered each year in a private university is not fixed, which results in an unstable faculty. Private colleges and universities have to recruit some part-time teachers when the number of students enrolled is beyond the normal one, but lack management of those part-time teachers and a strict rule of reward and punishment, which are also some problems of college English teaching in private colleges and universities.

\subsection{The Aspect of Students}

With the expansion policy of college students' enrollment, there is a fierce competition between universities. Students in private colleges and universities possess different levels of English. Some students are from Jiangsu Province and Zhejiang Province with a good command of English, while most students have a poor foundation of English, some students only got 30 points or less in College Entrance Examination. After entering the university, English become a burden to some students. They cannot follow teachers' instructions, even cannot understand in class. Under great pressure, those students do not dare to speak English or are unwilling to speak English lest they would make errors. Moreover, it is mainly teachers that explain in class with a dull atmosphere and students are very passive in learning. On the other hand, leaders of private colleges and universities are in a blind pursuit of high rate of students' passing CET 4 and CET 6 in order to improve the ranking of the university and make them more influential. Teachers have to concentrate on the drills of students' grammar and cultivate students' test capacities in a traditional manner. The result is that 
students are less interested in English and motivated in learning and classes just become teachers' matter. Moreover, some students are accustomed to the learning mode of middle school, and cannot adapt to the way of self-teach. Many students think that their English has decreased instead of improving after entering the university, so they are more reluctant to learn English, and even give up learning English in the end.

\section{The Reform Measures of College English Teaching in Private Colleges and Universities.}

The reform of college English teaching should serve students' study of those subjects in their specialties and students' future employment, build a good environment for English learning and pay much attention to the improvement of students' listening and speaking skills and comprehensive abilities. Therefore, reforms should be made in curriculum setting, teaching mode and evaluation system respectively.

\subsection{The Curriculum Setting}

Some of the students in universities think that their English has not improved, but declined greatly; others think they have not got too much from this course. Many a student feels bored, unmotivated and even shows intense antipathy to college English. It is not surprising that college English is blamed and some people even call for the cancellation of the course. Why is it ? Shu Dingfang made an all-sided analysis of college English teaching and got a conclusion that there are 9 problems about college English teaching and lack of Needs Analysis ranks no. 2 in the 9 problems. Cai Jigang believes that the reason why students are slack and uninterested in class is that students learn English just for the sake of English and that they are driven only by language learning. This teaching mode can't satisfy not only students' needs of learning language, but also their needs of employment after graduation. In Liu Runqing's opinion, with the development of the society, English teaching is bound to be combined with the subjects of a specific major and English for Specific Purpose (ESP) will be the mainstream of college English teaching in the 21st century. Students have no clear goals, no motivation and pressure, and no interests while learning English, which are some chief obstacles in the course of English learning. Therefore, the reform of college English teaching should adapt to the needs of social development and the needs of students' future employment. English for Specific Purpose (ESP) should be included in the curriculum system of college English. The purpose of setting courses of ESP is to cultivate students' ability of using English in an authentic environment. Learning English for General Purpose (EGP) is the basis of ESP, and ESP is an extension of EGP. In the first year, students are provided with EGP and trained for the basic English skills, including listening, speaking, reading, writing and translating skills, esp. the weak part of listening and speaking skills. In the second year, some relevant courses of ESP should be offered to students according to their majors. Private colleges and universities should insist on the philosophy that the key point is to train students' comprehensive abilities, shift from exam-oriented teaching into ability-oriented teaching and set an occupation-charactered curriculum of college English to improve students' abilities of application. The purpose of setting ESP is to cultivate students' interests in learning, focus on students' communicative skills in English and train students' pragmatic competence in a particular field rather than teach students knowledge of a specific subject. Teachers should help students to master the essential English skills in a specific major so that students can study the subjects effectively with the help of English and communicate with others in English when they work in the future. What's more, private colleges and universities should choose textbooks suitable to the actual level of their students' English. Some universities should try to write English textbooks for their own students according to the characteristics of majors if there is an excellent teachers' team.

\subsection{The Teaching Mode}

As far as the English level of students in private colleges and universities is considered, there is a big gap between each other. Many students were not admitted into public universities due to their poor English. Therefore, teachers should go beyond the traditional teaching mode, develop new 
teaching mode appropriate for their own students. Teachers should consider the actual English level of students and their future needs of employment when they set the learning objectives and learning tasks for students. There should be different standards to students of different majors, not a single one to all students. Otherwise students may be less interested in English or even give up learning English for fear of difficulties.

First of all, teachers should take into serious considerations the goals which students should reach in the aspects of knowledge, skills, emotions and abilities, and then they should make a reasonable teaching design about the whole teaching process. Afterwards, various useful resources should be selected for students' autonomous learning. Teachers should make microlectures about the key points and difficulties or choose some excellent microlectures from other teachers for students and also provide students with the learning tasks, questions, homework and project tasks in the process of autonomous learning. Students in each class are divided into groups according to their actual English level and for one group there are at most six persons, including some students with solid foundations of English and willingness to learn English and other students with poor English. In this way, students can help each other and make progress together when finishing the tasks assigned by teachers, which greatly increases the interactions and communications among students. For example, there is a unit in College English intensive reading, the subject of which is that a mother and her son learn more from a moment of defeat than they could from a victory. The task for each group is to do an interview or make a video about the persons who have the most profound influence on the group members in the process of growth. Such learning tasks have become a work process for each group. The members not only have improved their oral English, but also improved the ability to produce video, the ability to collaborate, the skills to interview, etc. in the process of completing the task.

Secondly, each group makes a presentation about the learning tasks or projects completed by the group members in the forms of PPT, video, sitcom, etc. in the class. The following is the process of assessment, including self-assessment by each group, the assessment by teachers and other group. Each group can learn the strengths from other groups and make up for their shortcomings. In class, students are very active, and both their English and ability of information technology application are improved. What's more, teachers make explanations on what puzzles students and give evaluation and feedback on students' work, which can let students strengthen their knowledge after class. In this way, students become the main body of the teaching process, teachers just lead students to the unknown. This teaching mode can greatly improve students' self-teach ability, cooperative ability, comprehensive ability of application, etc..

Lastly, teachers not only can interact with students in class, also after class through various on-line platforms. Students may have some problems and confusions unsolved in class because of the time limitation and then they can ask teachers and other students for help after class on the on-line platforms. For those shy students, they may prefer this approach, which can eliminate their nervousness and anxieties and achieve better effects.

In addition, private colleges and universities generally have the problem of reduction of class hours and credits. Therefore, the first class should be combined with second class and third class reasonably, which are the extension of the first class and can arouse students' enthusiasm for English.

\subsection{The Evaluation System}

Private universities should make some corresponding reforms in the evaluation system. The traditional mode of final evaluation should be replaced by the combination of formative evaluation and final evaluation. There should be different evaluation systems with different majors. Students majoring in art, for instance, should be judged mainly by the scores they got in the process of formative evaluation. Teachers should emphasize students' participations and their enjoyment in the learning process rather than let college English learning become a nightmare for these students. Students should learn some useful English which is helpful in their future employment. 


\section{Conclusion}

The reform of college English teaching in private colleges and universities is a great responsibility we educators should take on. Private colleges and universities should construct reasonable curriculum system of college English, including constantly perfecting English courses for general purpose which can train students' basic English skills, and gradually opening some courses for specific purpose suitable to different majors. Textbooks should be selected according to the actual English level of students in different majors. Teachers should also explore new appropriate teaching mode and approaches to improve students' autonomous learning ability and comprehensive ability to use English instead of adopting the traditional teaching mode, let students learn in doing, do in learning, learn happily and get achievements. In this way, private colleges and universities can cultivate technical talents who can meet the increasing needs of economic globalization. In terms of the evaluation system, the proportion of formative evaluation should be increased and that of final evaluation should be decreased, so that students can be enthusiastic about the group tasks in the process of learning and try their best to finish their group tasks. There is still a long way to go in the reform of college English teaching in private colleges and universities. Teachers and educators should constantly explore better teaching mode to meet the needs of students' future development and let students get what they need in English learning.

\section{References}

[1] "College English curriculum requirements" (the ministry of education) 2007

[2] Cai Jigang. "A Study on College English Curriculum Setting and Teaching Objectives"[J]: Foreign Language Teaching and Research, 2011, (4): 609-617

[3] Liu Runqing, Dai Manchun. Reform of Foreign Language Teaching in Chinese Universities: Research on Current Situation and Development Strategy[M]. Foreign Language Teaching and Research Press, 2003

[4] Rod Ellis. Understanding Second Language Acquisition[M]. Shanghai Foreign Language Education Press, 1999 